\title{
Relationships Between Black Pod and Witches'-Broom Diseases in Theobroma cacao
}

\author{
J.-M. Thevenin, R. Umaharan, S. Surujdeo-Maharaj, B. Latchman, C. Cilas, and D. R. Butler
}

First and fifth authors: Centre de Coopération Internationale en Recherche Agronomique pour le Développement (CIRAD), Département des Cultures Pérennes, UPR Maîtrise des Bioagresseurs des Cultures Pérennes, TA 80/02, 34398 Montpellier Cedex 5, France; and second, third, fourth, and sixth authors: Cocoa Research Unit, The University of the West Indies, St. Augustine, Trinidad and Tobago. Accepted for publication 28 June 2005.

\begin{abstract}
Thevenin, J.-M., Umaharan, R., Surujdeo-Maharaj, S., Latchman, B., Cilas, C., and Butler, D. R. 2005. Relationships between black pod and witches'-broom diseases in Theobroma cacao. Phytopathology 95:13011307.

Field observations were conducted from 1998 to 2001 at the International Cocoa Genebank, Trinidad, to evaluate 57 cacao clones for resistance to black pod (BP) and witches'-broom (WB) diseases (caused by Phytophthora sp. and Crinipellis perniciosa, respectively). Each month ripe pods were harvested and the number of healthy and diseased was recorded. The number of brooms on vegetative shoots was recorded three times a year on selected branches. Twenty-three clones showed less than $10 \%$ of infection for both BP and WB on pods. Among those, eight clones showed an absence of brooms on the observed branches: IMC 6,
\end{abstract}

ABSTRACT
MAN 15/60 [BRA], PA 67 [PER], PA 195 [PER], PA 218 [PER], PA 296 [PER], PA 303 [PER], and POUND 32/A [POU]. Broad-sense heritability was estimated at 0.38 and 0.57 for WB disease on pods and shoots, respectively, and at 0.51 for BP disease. Genetic correlation between WB disease on pods and on shoots was low and estimated at 0.39 , whereas the correlation between WB and BP diseases on pods was 0.48. To choose putative parents for breeding schemes, it is suggested that clones are first assessed for their level of resistance to $\mathrm{WB}$ on shoots, and the most promising individuals are screened for $\mathrm{BP}$ with a detached pods test. Further studies are needed to confirm whether the level of resistance to WB on pods can be predicted using an early test on seedlings.

Additional keywords: cocoa diseases, field resistance, germ plasm evaluation, polygenic resistance.
Cacao (Theobroma cacao L.) is prone to attack by numerous fungal pathogens, and two of the most economically important diseases are black pod (BP) and witches'-broom (WB) caused by Phytophthora sp. and Crinipellis perniciosa, respectively. BP is widely distributed throughout all cacao growing areas in the world and is ranked as the number one disease of cacao (51), with annual estimates of global crop losses of about $30 \%(25,30)$ and losses up to $90 \%$ in some locations $(7,10)$. The impact of BP is especially severe in some regions of West and Central Africa, which accounts for some 60 to $70 \%$ of the world's cocoa bean production (7). WB is currently restricted to the western hemisphere and found in several South American countries such as Brazil, Columbia, Ecuador, Peru, and Venezuela, part of Panama in Central America, and in several islands in the Caribbean. It is ranked as the second most debilitating disease of cacao, with annual estimates of crop losses ranging from 30 to $90 \%(15,41)$. In Brazil alone, in just 10 years since the appearance of the disease in the state of Bahia, the annual production of cocoa beans has dropped from 400,000 to 100,000 metric tonnes (7).

Major economic losses for both diseases result from infection on pods. At the onset of the rainy season, Phytophthora sp. resumes its activity and produces sporocysts. Zoospores are released in free water and spread to their target by splashing from the litter, the soil, or already sporulating pods or other affected cacao tissues or by animals among others $(28,29)$. When they land on the surface of cherelles or pods, they germinate and germ tubes penetrate through stomata or to a less extent by direct penetration through the exocarp of the pod $(22,49)$. First symptoms will

Corresponding author: J.-M. Thevenin; E-mail address: jean-marc.thevenin@ @irad.fr

DOI: 10.1094/PHYTO-95-1301

(C) 2005 The American Phytopathological Society appear 2 to 3 days after the attack as brown lesions that will develop quickly into a large brown rotten spot. Beans will be more or less affected by the rot and may be salvaged in case of a late attack, i.e., when pods have already started to ripen (34). For $\mathrm{WB}$, the parasitic phase of the life cycle is initiated by alternate periods of wetness and dryness, necessary for necrosed cacao tissues to produce basidiocarps. Released basidiospores landing on the wet surface of growing pods will germinate and penetrate the tissues, through stomata or possibly directly as observed on leaves by Sreenivasan and Dabydeen (46) or Frias et al. (17). A variety of symptoms can be observed depending on the stage of the cherelle when attack occurred: hypertrophy/distortion of the cherelle, necrotic lesions, chlorosis, and premature ripening. Indirect infection can also occur via the mycelium of $C$. perniciosa growing through the stalk of the cherelles or the pedicel of the flowers, leading to strawberry or carrot shape fruits $(9,40,44)$.

The effect of BP and WB can also be indirect. Phytophthora sp. can attack young flushes and roots but more importantly the trunk and branches of the tree causing cankers (4). The indirect effect of WB is characterized by attacks of the young meristematic tissues of both reproductive (flower cushions) and vegetative parts of the plant, reducing production by debilitating the tree's productive potential through diverting assimilates to brooms (7). In this case, the range of symptoms can be particularly wide and includes thickening of the flower pedicel, vegetative cushion brooms, swelling and necrosis of leaf petioles, stem canker, and axillary or terminal vegetative brooms $(40,44)$. In all cases, the parasitic large and intercellular mycelium of $C$. perniciosa growing in green meristematic tissues will convert to a thinner, intracellular mycelium concomitantly to the drying of the affected cacao tissues. This initiates the saprophytic stage of the life cycle, which will last until the emergence of the basidiocarps (14).

Cultural practices and the use of chemicals, especially for BP, have been the traditional methods of control for these diseases. 
However, the use of resistant material seems to be the best longterm and cost-effective method of control. The breeding program of the Ministry of Agriculture of Trinidad and Tobago, which started in the 1950s and led to the development of the Trinidad selected hybrids, focused on yield components, flavor, and resistance to $C$. perniciosa and Ceratocystis fimbriata, which were the most important pathogens at this time (18) and gave less consideration to BP, which is now a major concern (43). It is therefore valuable to include in breeding programs sources of resistance to all major threatening diseases. In addition, for diseases such as WB, it is important to include sources of resistance to the different forms of the disease, if they are inherited independently. As several screening programs for resistance to WB are now being conducted in nurseries, using an inoculation test on vegetative parts of the plant $(27,38,50)$, it is important to verify how the level of resistance on shoots is correlated to the level of resistance on pods, which strongly affects cocoa yields. Therefore, field data on disease resistance, which includes pods, is very important in identifying resistant genotypes (51).

The aim of this study is to investigate relationships between BP and the different forms of WB based on field observations under natural conditions of infection.

\section{MATERIALS AND METHODS}

Field observations were conducted over a 36-month period from November 1998 to October 2001 (i.e., three cropping seasons) on 57 clones, representing 20 accession groups (clones with a common group name), at the International Cocoa Genebank, Trinidad (ICG,T), as part of a wider project aimed at assessing the resistance of cacao to $\mathrm{BP}$ and $\mathrm{WB}$ under natural conditions of infection (Table 1).

Criteria for the selection of some clones were their known resistance or susceptibility to $\mathrm{WB}$ and $\mathrm{BP}$ and their suitability for use as controls (seven clones: EET 59 [ECU], ICS 1, IMC 57, NA 45, PA 120 [PER], SCA 6, and UF 11). The remaining 50 clones were selected on the basis of various other interesting traits such as low pod index, high butter fat content, and flavor. In the ICG,T, each accession is represented by a single block of 1 to 16 trees, planted under shade provided by trees of Erythrina sp. Depending on the availability of trees for each clone, three to five trees were selected to assess symptoms of BP on pods and of WB both on pods and shoots: 47 clones were represented by five trees, 5 clones by four trees, and 5 clones by three trees.

Within a clone, trees were chosen for their similarity to each other based on the color of flushes and color and shape of pods to avoid the use of any off-type trees, which is a potential problem in most cacao genebanks (32). To ensure the correct identity of the selected trees, some of them had been characterized using molecular tools and compared with a reference tree when such still existed. Any trees shown to be mislabeled were eliminated from the study.

Disease observations on pods and shoots. Each tree was observed monthly, ripe pods were harvested, and the following variables were recorded: number of healthy pods, number of pods with BP symptoms but no WB symptoms, number of pods with WB symptoms but no BP symptoms, and number of pods with both BP and WB symptoms on the same pod. Symptoms were noted regardless of associations with damage by other fungi (Colletotrichum sp., Botryodiplodia sp.), insects, rodent, or bird attack. At the end of each cropping season, the numbers of affected pods and healthy pods harvested each month were added and yearly percentages of pods affected by BP and WB were estimated by dividing the number of infected pods for each disease by the total number of pods. For observations on shoots, three branches of approximately $1.5 \mathrm{~m}$ in length were selected to represent the canopy from each selected tree. On each branch, records were taken of the number of healthy shoots, green brooms, and dry brooms, and these brooms were tagged. The observations on shoots were made three times per year, in November, March, and July. At the end of each year, all brooms tagged during the considered period were added and the percentage of shoots affected by WB was expressed as the number of shoots with WB symptoms divided by the total number of shoots. Symptoms on flower cushions were not recorded.

Analysis of data. Percentages of pods affected by WB and BP and the percentage of shoots affected by WB were subjected to an arcsine square root transformation before analysis: $y=\sin ^{-1}(\sqrt{x})$ (26). Analysis of data was performed using the mixed model for repeated measures with special parametric structure on the covariance matrices (compound symmetric, autoregressive order one, and unstructured) to determine the significance of the differences observed among clones and among years for the different traits (52). In this model, covariance is estimated using the restricted maximum likelihood estimation model and covariance structure is chosen based on the Akaike' information criterion. This model takes into consideration the correlation that may exist between years for individual tree data. Broad-sense heritability and the associated confidence interval at $95 \%$ were estimated using the Wald method (1). Statistical analyses and estimates of broad-sense heritability were performed using the SAS system (SAS Institute, Cary, NC) (42). Relationships between variables and between years for the same variable were assessed with NCSS 2001 (19) using Pearson and Spearman rank coefficients of correlation.

\section{RESULTS}

Mixed model analysis was performed on 56 clones only for the percentage of pods affected by $\mathrm{BP}$ or WB, as clone JA 1/21 [POU] did not produce sufficient pods (i.e., less than six pods per tree per year). However, the analysis was performed on the 57 clones for the percentage of shoots affected by WB. Analyses showed highly significant clonal and year effects for all variables: percentage of pods infected by BP, percentage of pods infected by $\mathrm{WB}$, and percentage of shoots infected by WB. Clone-year interactions were significant as well but their effect was less important than the individual effects as suggested by the $F$ values (Table 2). The "unstructured" covariance structure used in the model gave the best accuracy during the analysis of the percentage of pods infected by BP and by WB, whereas the "auto regressive (rank 1)" covariance structure was the most suitable when analyzing the percentage of shoots infected by WB.

The overall percentage of BP was estimated at $16.2 \%$. It varied considerably from 1 year to the other, clearly increasing from year 1 to year $3(8.3 \%$ in year $1,12.3 \%$ in year 2 , and $33.2 \%$ in year 3$)$. Clone-year interactions were significant but weak $(F=$ 2.35), meaning that the classification of clones varied slightly from year to year. This is confirmed by the genetic correlation between years that was highly significant but the coefficient $(r)$ was not very high (Table 3$)$. There were significant differences $(P \leq$ $0.001)$ between clones and a large variation was observed for this trait, the most resistant clone (PA 296 [PER]) having 1.8\% of its pods affected by BP and the most susceptible (ICS 70) having almost $68 \%$ (Table 1). Several clones showed some promise with a low percentage of pods affected by BP, e.g., B 12/1 [POU], LX 31, MAN 15/60 [BRA], NA 142, NA 680, PA 120 [PER], PA 195 [PER] PA 202 [PER], PA 296 [PER], PA 303 [PER], POUND 32/A [POU], and SPEC 185/4. However, several clones were highly susceptible to BP and had more than $50 \%$ of pods affected, i.e., CRU 119, CRU 96, and ICS 70. The broad-sense heritability for BP was estimated at $0.39,0.67$, and 0.47 for years 1,2 , and 3 , respectively, with an average of 0.51 (Table 4).

Under the prevailing disease pressure, the average percentage of pods affected by WB (3.8\%) was much lower than for BP. It decreased from $7.1 \%$ in year 1 to $3.2 \%$ in year 2 and $2.0 \%$ in year 
$3(F=20.39)$. The clone-year interaction was also significant and weak $(F=1.64)$ with Spearman coefficients of correlation between years varying from 0.34 to 0.53 only (Table 3 ). Significant differences $(P \leq 0.001)$ between clones were also observed for $\mathrm{WB}$ on pods and the percentage varied between $0 \%$ (for PA 120
[PER] and PA 296 [PER]) and 25.6\% for UF 11 (Table 1). Fourteen clones had less than $1 \%$ of pods affected by WB and could represent an interesting basis for germ plasm enhancement for WB resistance, whereas only a few clones were considered to be very susceptible, e.g., EET 59 [ECU], NA 45, NA 672, and UF 11.

TABLE 1. Expression of black pod and witches'-broom diseases on cacao genotypes in the field ${ }^{\mathrm{a}}$

\begin{tabular}{|c|c|c|c|c|c|c|}
\hline \multirow[b]{3}{*}{ Genotypes } & \multirow{2}{*}{\multicolumn{2}{|c|}{$\begin{array}{c}\text { Black pod disease } \\
\text { on pods }(\%)^{\mathrm{b}}\end{array}$}} & \multicolumn{4}{|c|}{ Witches'-broom disease } \\
\hline & & & \multicolumn{2}{|c|}{ on pods $(\%)^{\mathrm{c}}$} & \multicolumn{2}{|c|}{ on shoots $(\%)^{\mathrm{d}}$} \\
\hline & Transformed value & Mean value & Transformed value & Mean value & Transformed value & Mean value \\
\hline AM 1/73 [POU] & 0.27 & 7.2 & 0.21 & 4.2 & 0.01 & 0.01 \\
\hline AM 2/65 [POU] & 0.29 & 8.0 & 0.24 & 5.7 & 0.01 & 0.02 \\
\hline AMAZ 12 [CHA] & 0.39 & 14.6 & 0.06 & 0.3 & 0.00 & 0.00 \\
\hline B $5 / 3$ [POU] & 0.49 & 21.9 & 0.28 & 7.8 & 0.10 & 0.91 \\
\hline B 12/1 [POU] & 0.20 & 4.1 & 0.10 & 1.0 & 0.02 & 0.04 \\
\hline B 13/5 [POU] & 0.32 & 9.8 & 0.20 & 3.9 & 0.02 & 0.04 \\
\hline CL $10 / 10$ & 0.41 & 16.1 & 0.32 & 10.1 & 0.03 & 0.12 \\
\hline CL 19/10 & 0.34 & 10.8 & 0.08 & 0.7 & 0.02 & 0.03 \\
\hline CLEM /S-62-1 & 0.46 & 20.0 & 0.16 & 2.5 & 0.00 & 0.00 \\
\hline CRU 19 & 0.45 & 19.0 & 0.09 & 0.9 & 0.01 & 0.01 \\
\hline CRU 96 & 0.96 & 67.4 & 0.38 & 13.7 & 0.13 & 1.65 \\
\hline CRU 119 & 0.80 & 51.2 & 0.35 & 12.0 & 0.18 & 3.27 \\
\hline EET 58 [ECU] & 0.36 & 12.5 & 0.33 & 10.7 & 0.12 & 1.38 \\
\hline EET 59 [ECU] & 0.57 & 29.2 & 0.40 & 15.3 & 0.17 & 2.81 \\
\hline ICS 1 & 0.57 & 29.2 & 0.29 & 8.3 & 0.09 & 0.76 \\
\hline ICS 40 & 0.56 & 28.5 & 0.13 & 1.6 & 0.04 & 0.15 \\
\hline ICS 70 & 0.97 & 67.9 & 0.24 & 5.6 & 0.01 & 0.01 \\
\hline ICS 84 & 0.54 & 26.1 & 0.12 & 1.4 & 0.13 & 1.61 \\
\hline ICS 95 & 0.52 & 24.5 & 0.31 & 9.5 & 0.04 & 0.16 \\
\hline IMC 6 & 0.23 & 5.1 & 0.18 & 3.3 & 0.00 & 0.00 \\
\hline IMC 16 & 0.29 & 8.3 & 0.13 & 1.8 & 0.01 & 0.01 \\
\hline IMC 47 & 0.25 & 6.0 & 0.12 & 1.5 & 0.02 & 0.03 \\
\hline IMC 57 & 0.46 & 19.4 & 0.17 & 3.0 & 0.00 & 0.00 \\
\hline IMC 103 & 0.65 & 36.6 & 0.17 & 2.9 & 0.02 & 0.03 \\
\hline JA 1/21 [POU] & n.a. & n.a. & n.a. & n.a. & 0.04 & 0.19 \\
\hline JA 5/25 [POU] & 0.46 & 19.3 & 0.28 & 7.8 & 0.03 & 0.11 \\
\hline LP 1/45 [POU] & 0.36 & 12.1 & 0.21 & 4.3 & 0.00 & 0.00 \\
\hline LP 4/24 [POU] & 0.31 & 9.5 & 0.09 & 0.9 & 0.09 & 0.86 \\
\hline LX 31 & 0.16 & 2.7 & 0.32 & 9.8 & 0.05 & 0.25 \\
\hline MAN 15/60 [BRA] & 0.20 & 3.9 & 0.11 & 1.3 & 0.00 & 0.00 \\
\hline MOQ 5/5 & 0.54 & 26.6 & 0.27 & 7.0 & 0.00 & 0.00 \\
\hline NA 8 & 0.33 & 10.5 & 0.17 & 3.0 & 0.01 & 0.01 \\
\hline NA 45 & 0.70 & 41.1 & 0.51 & 24.2 & 0.22 & 4.68 \\
\hline NA 142 & 0.20 & 3.8 & 0.21 & 4.4 & 0.06 & 0.32 \\
\hline NA 149 & 0.71 & 42.5 & 0.36 & 12.1 & 0.01 & 0.01 \\
\hline NA 178 & 0.64 & 35.7 & 0.22 & 5.0 & 0.00 & 0.00 \\
\hline NA 226 & 0.70 & 41.6 & 0.19 & 3.7 & 0.00 & 0.00 \\
\hline NA 342 & 0.24 & 5.8 & 0.12 & 1.4 & 0.04 & 0.17 \\
\hline NA 387 & 0.45 & 19.2 & 0.08 & 0.7 & 0.03 & 0.06 \\
\hline NA 672 & 0.50 & 22.9 & 0.47 & 20.9 & 0.07 & 0.47 \\
\hline NA 680 & 0.20 & 3.8 & 0.10 & 0.9 & 0.02 & 0.03 \\
\hline NA 756 & 0.49 & 21.8 & 0.38 & 13.5 & 0.00 & 0.00 \\
\hline PA 34 [PER] & 0.26 & 6.5 & 0.06 & 0.3 & 0.05 & 0.24 \\
\hline PA 67 [PER] & 0.31 & 9.1 & 0.13 & 1.7 & 0.00 & 0.00 \\
\hline PA 70 [PER] & 0.62 & 34.0 & 0.16 & 2.7 & 0.11 & 1.28 \\
\hline PA 120 [PER] & 0.14 & 2.0 & 0.00 & 0.0 & 0.01 & 0.02 \\
\hline PA 151 [PER] & 0.70 & 41.2 & 0.02 & 0.1 & 0.00 & 0.00 \\
\hline PA 169 [PER] & 0.37 & 13.0 & 0.10 & 0.9 & 0.00 & 0.00 \\
\hline PA 195 [PER] & 0.18 & 3.2 & 0.03 & 0.1 & 0.00 & 0.00 \\
\hline PA 202 [PER] & 0.21 & 4.3 & 0.11 & 1.1 & 0.06 & 0.41 \\
\hline PA 218 [PER] & 0.32 & 9.7 & 0.21 & 4.4 & 0.00 & 0.00 \\
\hline PA 296 [PER] & 0.13 & 1.8 & 0.00 & 0.0 & 0.00 & 0.00 \\
\hline PA 303 [PER] & 0.18 & 3.1 & 0.07 & 0.5 & 0.00 & 0.00 \\
\hline POUND 32/A [POU] & 0.17 & 2.7 & 0.20 & 4.1 & 0.00 & 0.00 \\
\hline SCA 6 & 0.39 & 14.6 & 0.04 & 0.2 & 0.01 & 0.01 \\
\hline SPEC 185/4 & 0.15 & 2.4 & 0.17 & 3.0 & 0.03 & 0.10 \\
\hline UF 11 & 0.57 & 29.2 & 0.53 & 25.6 & 0.27 & 7.35 \\
\hline Mean & 0.41 & 16.2 & 0.20 & 3.8 & 0.04 & 0.17 \\
\hline $\operatorname{LSD}(P<0.05)$ & 0.24 & & 0.17 & & 0.08 & \\
\hline
\end{tabular}

a Observations were made in the International Cocoa Genebank, Trinidad, between 1998 and 2001.

b Pods were harvested monthly and the number with black pod symptoms was recorded as a percentage of the total.

c Pods were harvested monthly and the number with witches'-broom symptoms was recorded as a percentage of the total.

$\mathrm{d}$ The number of vegetative brooms on selected branches was recorded three times a year and is given as a percentage of the total number of shoots.

e Transformed values were based on arcsine square root transformation. 
The broad-sense heritability for $\mathrm{WB}$ on pods was estimated at $0.39,0.45$, and 0.29 in years 1,2 , and 3 , respectively, with an average of 0.38 (Table 4 ).

The average percentage of shoots affected by WB was $0.17 \%$. It varied from year to year but ratios between years were smaller and more consistent than for diseased pods $(0.20 \%$ in year 1 , $0.22 \%$ in year 2 , and $0.11 \%$ in year 3 ). Contrary to affected pods, the effect of year $(F=7.57)$ was smaller than the effect of clone for this variable (Table 2). Even though the clone-year interaction was highly significant, its effect was small and the correlation between years was highly significant and varied from 0.64 to 0.81 for Spearman coefficients of correlation. Significant differences $(P \leq 0.001)$ between clones were observed and the percentage varied between 0 and $7.35 \%$ (Table 1). Eighteen clones did not have any shoots affected by WB during the period of observation, whereas a few clones are considered to be very susceptible, e.g., CRU 119, EET 59 [ECU], NA 45, and UF 11. The broad-sense heritability for $\mathrm{WB}$ on shoots was estimated at $0.56,0.70$, and 0.45 in years 1,2 , and 3 , respectively, with an average of 0.57 (Table 4).
BP was significantly correlated to $\mathrm{WB}$ on pods with the Spearman coefficient of correlation estimated at $0.48(P \leq 0.001)$, whereas BP was not significantly correlated at a 5\% level to WB on shoots $(r=0.25, P=0.059)$. A significant correlation $(r=0.39$, $P=0.003)$ was also observed between $\mathrm{WB}$ on pods and WB on shoots (Table 5).

\section{DISCUSSION}

The 57 clones observed belong to a total of 20 different accession groups. Most of the clones belong to the Upper Amazon Forastero (IMC, NA, PA, POUND, and SCA) and to the Refractario (AM, B, CL, and LP) groups, which are well represented in the ICG,T. They originated from expeditions to Peru and Ecuador during the first half of the past century, for which the objective was to search for sources of resistance to WB, soon after the first outbreak of the disease in Trinidad (3). However, Lower Amazon Forastero (MAN) and Trinitario (ICS and UF) groups, which had not been selected for their resistance to $\mathrm{WB}$, were also represented, as well as some clones from unidentified groups (CRU)

TABLE 2. Mixed model analysis for field resistance of cacao to black pod and witches'-broom diseases ${ }^{\mathrm{a}}$

\begin{tabular}{|c|c|c|c|c|c|}
\hline Observation & Source & df & Chi-square & $F$ value & $P>F$ \\
\hline Black pod & $\begin{array}{l}\text { Clone } \\
\text { Year } \\
\text { Clone } \times \text { year }\end{array}$ & $\begin{array}{r}55 \\
2 \\
110\end{array}$ & $\begin{array}{l}520.07 \\
146.67 \\
258.88\end{array}$ & $\begin{array}{r}9.46 \\
73.33 \\
2.35\end{array}$ & $\begin{array}{l}P<0.0001 \\
P<0.0001 \\
P<0.0001\end{array}$ \\
\hline Witches'-broom on shoots & $\begin{array}{l}\text { Clone } \\
\text { Year } \\
\text { Clone } \times \text { year }\end{array}$ & $\begin{array}{r}56 \\
2 \\
112\end{array}$ & $\begin{array}{r}627.75 \\
15.13 \\
202.71\end{array}$ & $\begin{array}{r}11.21 \\
7.57 \\
1.81\end{array}$ & $\begin{array}{l}P<0.0001 \\
P=0.0006 \\
P<0.0001\end{array}$ \\
\hline
\end{tabular}

${ }^{a}$ Observations were made in the International Cocoa Genebank, Trinidad, between 1998 and 2001.

TABLE 3. Spearman and Pearson correlation between years for field observations on black pod and witches'-broom diseases of cacao in the International Cocoa Genebank, Trinidad, from 1998 to 2001

\begin{tabular}{|c|c|c|c|c|c|}
\hline \multirow[b]{2}{*}{ Observation } & \multirow[b]{2}{*}{ Parameters } & \multicolumn{2}{|c|}{ Spearman } & \multicolumn{2}{|c|}{ Pearson } \\
\hline & & Correlation coefficient & $P>F$ & Correlation coefficient & $P>F$ \\
\hline Black pod & $\begin{array}{l}1998 / 99 \text { vs. } 1999 / 2000 \\
1998 / 99 \text { vs. } 2000 / 01 \\
1999 / 2000 \text { vs. } 2000 / 01\end{array}$ & $\begin{array}{l}0.65 \\
0.49 \\
0.44\end{array}$ & $\begin{array}{l}P<0.0001 \\
P=0.0001 \\
P=0.0006\end{array}$ & $\begin{array}{l}0.68 \\
0.44 \\
0.44\end{array}$ & $\begin{array}{l}P<0.0001 \\
P=0.0006 \\
P=0.0007\end{array}$ \\
\hline Witches'-broom on pods & $\begin{array}{l}1998 / 99 \text { vs. } 1999 / 2000 \\
1998 / 99 \text { vs. } 2000 / 01 \\
1999 / 2000 \text { vs. } 2000 / 01\end{array}$ & $\begin{array}{l}0.35 \\
0.34 \\
0.53\end{array}$ & $\begin{array}{l}P=0.0072 \\
P=0.0113 \\
P<0.0001\end{array}$ & $\begin{array}{l}0.41 \\
0.38 \\
0.56\end{array}$ & $\begin{array}{l}P=0.0020 \\
P=0.0034 \\
P<0.0001\end{array}$ \\
\hline
\end{tabular}

TABLE 4. Broad-sense heritability for black pod and witches'-broom on cacao, based on observations in the International Cocoa Genebank, Trinidad, between 1998 and 2001

\begin{tabular}{|c|c|c|c|c|}
\hline \multirow[b]{2}{*}{ Observation } & \multicolumn{4}{|c|}{$h^{2}$ [confidence interval at $95 \%$ ] } \\
\hline & 1998/99 & $1999 / 2000$ & $2000 / 01$ & Mean \\
\hline Black pod & $0.387[0.229-0.545]$ & $0.669[0.556-0.783]$ & $0.466[0.306-0.625]$ & 0.507 \\
\hline Witches'-broom on pods & $0.390[0.235-0.544]$ & $0.452[0.297-0.607]$ & $0.288[0.134-0.441]$ & 0.377 \\
\hline Witches'-broom on shoots & $0.560[0.438-0.682]$ & $0.701[0.605-0.797]$ & $0.447[0.315-0.518]$ & 0.569 \\
\hline
\end{tabular}

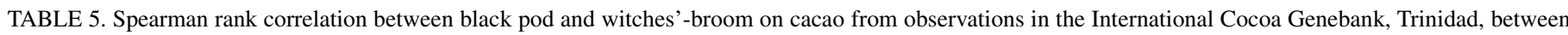
1998 and 2001

\begin{tabular}{|c|c|c|}
\hline Parameters & Correlation coefficients & Probability level \\
\hline Black pod vs. witches'-broom on pods & 0.48 & $P<0.001$ \\
\hline Black pod vs. witches'-broom on shoots & 0.25 & $P=0.059$ \\
\hline Witches'-broom on pods vs. witches'-broom on shoots & 0.39 & $P=0.003$ \\
\hline
\end{tabular}


likely to be from the Upper Amazon Forastero or Refractario groups. All clones were replanted in the 1980s in their present location in existing cocoa fields where disease pressure was already established.

The level of infection by WB on shoots was less than $1 \%$ for approximately $85 \%$ of the clones, and the global level of attack was low (estimated at $0.17 \%$ ). This could be explained by several reasons: (i) most of the clones were initially selected as seed from mother trees with apparent resistance to WB and, therefore, there is a good representation of WB resistance in the ICG,T; (ii) the pathotype ("B") of C. perniciosa present in Trinidad is less aggressive than pathotype "A" which is prevalent in Ecuador, Peru, and Colombia and would therefore induce a lower level of symptoms (54); and (iii) the number of shoots observed per clone is sometimes so large that percentages of infection will seem small even though clones are susceptible with clear symptoms. It is interesting to note that the most susceptible clones to WB on shoots include some that were selected for their productivity (EET 58 [ECU], EET 59 [ECU], ICS 84, and UF 11). They also include some clones that originated from trees selected for their apparent resistance during the expeditions (LP 4/24 [POU], NA 45 , and PA $70[\mathrm{PER}]$ ), but these clones, originally collected as seed, would have shown segregation in the progenies sown. The high correlation (Spearman or Pearson) between years of observations for WB on shoots, associated to a low, even though significant clone-year interaction demonstrates a tendency for observations of this character to be fairly stable from one year to another. The most susceptible clones (CRU 119, EET 59 [ECU], NA 45, and UF 11) have consistently developed large numbers of brooms over the years, and clones very resistant to WB on shoots consistently did not develop any symptoms. However, a few clones showing an irregular response to the attack of $C$. perniciosa contributed to the existence of this clone-year interaction: B 5/3 [POU], CRU 96, and PA 70 [PER] susceptible in year 1 and resistant or moderately resistant in year 3; ICS 40, ICS 95, and LP $4 / 24$ [POU] resistant or moderately resistant in year 1 but susceptible in years 2 and 3 .

The level of attack by Phytophthora sp. was moderately high (16.2\% globally over the period of observation). This is not surprising as no selection was reported to have been made for resistance to $\mathrm{BP}$ at the time of the collecting expeditions. In addition, the third year of observations was apparently favorable to Phytophthora sp. attacks and induced a higher disease level (31.2\%) than years 1 and 2. The level of attack by $C$. perniciosa on pods $(3.8 \%)$ was much lower than for BP. Twenty-three clones showed less than $10 \%$ of infection for both BP and WB on pods. Among those, eight clones showed an absence of brooms on the observed branches: IMC 6, MAN 15/60 [BRA], PA 67 [PER], PA 195 [PER], PA 218 [PER], PA 296 [PER], PA 303 [PER], and POUND 32/A [POU]. A few other interesting clones showing $0.1 \%$ or less shoots affected are also considered to be promising for breeding: AM 1/73 [POU], AM 2/65 [POU], B12/1 [POU], B 13/5 [POU], IMC 16, IMC 47, NA 680, PA 120 [PER], and SPEC 185/4. Other data such as pod index, bean size, or butter fat content are not available for all the promising clones; however, Iwaro et al. (20) observed that clones with a large bean number commonly show good resistance to BP. Furthermore, it should be noted that IMC 47 combines promising disease resistance with a low (27.4) pod index (20), high $(56.2 \%)$ butter fat content (53), and a productivity of 82 pods per year per tree over the concerned period. For symptoms on pods, whether due to Phytophthora sp. or C. perniciosa, the year effect is more important than for WB on shoots, as shown by existing clone-year interactions. For clones where the level of resistance or susceptibility to either disease was extreme, their rating proved to be fairly consistent among years; we can cite B 12/1 [POU], IMC 47, NA 680, PA 34 [PER], PA 120 [PER], PA 195 [PER], PA 296 [PER], and PA 303 [PER] consistently resistant to $\mathrm{BP}$ and $\mathrm{WB}$, and CRU 96, EET 59 [ECU],
NA 45, NA 672, and UF 11 consistently susceptible to both diseases. However, a few clones showed variation among years in their level of resistance to either disease and are considered to be responsible for the clone-year interaction; among those, we can mention B 5/3 [POU], MAN 15/60 [BRA], NA 8, and PA 169 [PER] for both BP and WB. Several factors can be pointed out as being partly responsible for the poor correlation between years of observations; these include variable environmental conditions, such as rainfall and inoculum pressure and variable fruit production characteristics from one year to another $(2,5,12)$. The global level of productivity was 25.9 pods per tree in year $1,30.1$ in year 2 , and 28.2 in year 3. An analysis of variance (data not shown) performed on this trait showed a highly significant clonal effect but a nonsignificant year effect or clone-year interaction, meaning that differences observed in the level of resistance to BP or WB cannot be explained by differences of fruit bearing between years. Cumulative rainfall data showed variation among cropping seasons: $1,865 \mathrm{~mm}$ in year $1,1,915 \mathrm{~mm}$ in year 2 , and $1,504 \mathrm{~mm}$ in year 3 . Year 3 was characterized by the least amount of rain but surprisingly induced the highest level of BP. However, November and December are 2 months when BP reaches a peak, and these 2 months were wetter in year $3(458 \mathrm{~mm}, 38$ rain days) than in year 1 (373 mm, 38 rain days) or year $2(421 \mathrm{~mm}, 19$ rain days). Detailed epidemiological studies should nevertheless be conducted in order to explain more accurately differences observed among years on the expression of cacao diseases.

Numerous authors have suggested that resistance to BP disease is polygenic and horizontal $(6,11,35,45,48)$, although recently, Efron et al. (13) expressed a belief that only three genes might be involved in the resistance to Phytophthora. In addition, the transmission of the resistance is additive and the level of resistance of progenies can be predicted by the level of resistance of the parents $(23,33)$. Our data estimated the average broad-sense heritability to be 0.51 for the 3 years, suggesting that $26 \%$ of the total variation observed can be explained by a genetic effect, for this particular character. Confidence intervals were narrow and indicated that estimates were fairly accurate. These estimates are within the same range of heritabilities, 0.32 and 0.68 , reported for field observations by Kébé et al. (24) in a $16 \times 4$ parent factorial trial in Côte d'Ivoire after 5 and 9 years, respectively. These estimates are however much higher than those given by Cilas et al. (8), i.e., 0.133 in Cameroon after 3 years of observations and 0.061 in Togo after 1 year. These authors suggested that the longer the period of observation, the more accurate the data and the higher the estimate of heritability. This emphasizes the need to conduct field observations on pods over long periods to reduce the source of variation. Our estimates of heritability for BP and other traits might well have been over-estimated due to the planting design of the genebank, where clones are represented by several trees in a single block, with no replication in any other block.

Several authors have also suggested that resistance to $\mathrm{WB}$ is horizontal and polygenic $(36,45,55)$. However, the low level of infection in progenies issued from the highly resistant clone SCA 6 led Pires et al. (37) to suggest that there is a large dominance and homozygocity for this character in SCA 6 and that only a few genes might be involved in the resistance to $\mathrm{WB}$ in this particular cultivar. In addition, Zadoks (55), quoting Montserin et al. (31) who compared reciprocal crosses of SCA 6 and ICS 1, suggested a maternal inheritance of resistance with the implication of extra nuclear genes. Our estimates of broad-sense heritability varied from 0.29 to 0.45 with an average of 0.38 for pods and from 0.45 to 0.70 with an average of 0.57 for shoots. These values tell us that, as for BP, a moderate part of the phenotypic variation observed in the field can be attributed to genetic effects, i.e., $14 \%$ for pods and $32 \%$ for shoots. Confidence intervals associated with the broad-sense heritability for WB on pods or shoots were also narrow, suggesting that estimates for these characters were fairly accurate. 
There was a significant relationship between $\mathrm{BP}$ and $\mathrm{WB}$ on pods even though it was not very strong $(r=0.48)$. It suggested that approximately $23 \%$ of the variation observed in BP could be accounted for as variation in WB. The relationship between BP on pods and WB on shoots was weaker and not significant, as would be expected since two different pathogens and two different organs are concerned. The genetic correlation between WB on pods and on shoots was moderate $(r=0.39)$. Some clones were indeed susceptible on shoots and resistant on pods (ICS 84, LP 4/24 [POU], and PA 70 [PER]), and other clones were susceptible on pods and resistant on shoots (NA 149 and NA 756). Based on field observations at the genebank of CEPEC (Centro de Pesquisas do Cacau), BA-Brazil, Pires et al. (36) obtained slightly lower correlations ( $r=0.24$ between $\mathrm{BP}$ and $\mathrm{WB}$ on pods and $r=0.36$ between WB on pods and WB on shoots) and suggested that resistance to both diseases may have evolved simultaneously and is contained in the same accessions.

Both pathogens produce spores during the rainy season, a time during which, after a dry season, trees bloom and produce cherelles and new vegetative shoots. In wet conditions, Phytophthora sp. will quickly produce a continuous, regular supply of zoospores that will attack pods of almost any age, whereas Crinipellis sp. requires alternate wet and dry periods to sporulate and produces irregular waves of basidiocarps. Both pathogens are able to penetrate cacao tissues directly or through stomata $(17,22,46)$. It could therefore be suggested that similar mechanisms of resistance are likely for both diseases at the penetration stage and this could account for part of the correlation between BP and WB on pods. However, many young cherelles could have been lost following attacks by Phytophthora during the first 3 months of their life and would not have been counted in this study. Attack by Crinipellis of older tissues might not lead to the development of visible symptoms and would therefore have been missed during the evaluation. These two reasons could explain why the correlation between BP and WB on pods is not very strong. In addition, our data showed an inverse relationship between BP and WB on pods among years, suggesting that a high level of BP will reduce the number of pods available for a potential attack by WB. This is supported by observations in Brazil, where BP was not an important disease in Bahia state when pod losses due to WB were very high and is becoming more and more important now that resistant planting material to WB has been planted (E. D. M. N. Luz, personal communication). Vegetative shoots are more susceptible to WB at their early stages of development (17), whereas pods will be susceptible for a longer period. As the production of both cacao shoots and basidiocarps are cyclic, the cycles could be out of phase for certain clones, which would lead to an escape from the disease for shoot infection but not for pod infection. This may explain the relatively weak but significant Spearman correlation $(r=0.39)$ between pod and shoot symptoms for WB.

Field observations are time consuming and laborious especially for pods and may be dependent on the environment. However, they provide valuable information about the level of resistance of trees in their field environment. In order to choose putative parents for breeding schemes and in order to overcome the difficulties of observations on pods, it could be suggested that clones are first assessed for their level of resistance to WB on shoots. These observations are stable in time in a well-established cacao plantation with high disease pressure as demonstrated by the coefficients of correlation of Spearman or Pearson (Table 3). In addition, observations on shoots could be facilitated by counting brooms only since the percentage of affected shoots is well correlated to the number of brooms; the Spearman coefficient of correlation for clones showing symptoms indeed varied from 0.79 to 0.92 among years $(P \leq 0.001$, data not shown). Clones selected for their good level of resistance to WB on shoots could then be evaluated for their level of resistance to BP, using a spray inoculation method on detached pods, which is a rapid and reliable method (21). Clones cumulating resistance to $\mathrm{WB}$ on shoots in the field and to BP in the laboratory represent an interesting basis for enhancement programs. They could be assessed for yield potential (pod index, bean size) and confirmed for their level of resistance on shoots to make sure they did not escape infection in the field, using a spray inoculation (39) or agar droplet (47) method. However, the prediction of the level of resistance to WB on pods using an early test on seedlings would only be possible if the correlation between these traits is confirmed. Indeed, the genetic cause of correlation between two characters is mainly pleiotrophy (16), i.e., when one gene affects several characters even though linkage between genes and natural selection (genes in common) can play a role as well. To investigate this interpretation, a further study is needed on the comportment of progenies issued from two crosses: a cross between a parent resistant to $\mathrm{BP}$ and susceptible to $\mathrm{WB}$ (on pods and shoots) and a parent susceptible to BP and resistant to WB (on pods and shoots) and another cross between parents both susceptible to BP, but one being resistant to $\mathrm{WB}$ on shoots and susceptible to $\mathrm{WB}$ on pods and the other one resistant to WB on pods and susceptible to WB on shoots. Such an experiment would clearly identify the level and types of correlation and provide evidence whether or not selection for resistance to one disease or one form of WB would be sufficient to increase the level of resistance to both $\mathrm{BP}$ and WB on pods and shoots.

\section{ACKNOWLEDGMENTS}

We thank the Common Fund for Commodities (CFC) for financial support, A. B. Eskes and P. Petithuguenin for encouragement, P. Umaharan for valuable advice, and all technical staff who helped during field assessment.

\section{LITERATURE CITED}

1. Agresti, A., and Coull, B. A. 1998. Approximate is better than "Exact" for interval estimation of binomial proportions. Am. Stat. 52:119-126.

2. Amponsah, J. D. 1988. Studies on field resistance of cocoa varieties to Phytophthora palmivora (Butl) Butl. infections. Pages 557-567 in: Proc. 10th Int. Cocoa Res. Conf., Santo Domingo, Dominican Republic. Cocoa Producers' Alliance (COPAL), UK.

3. Anonymous. 1999. The cocoa research unit-An overview. Pages 5-8 in: Annual Report 1998. Cocoa Research Unit, The University of the West Indies, Trinidad and Tobago.

4. Appiah, A. A., Opoku, I. Y., and Akrofi, A. Y. 2004. Natural occurrence and distribution of stem cankers caused by Phytophthora megakarya and Phytophthora palmivora on cocoa. Eur. J. Plant Pathol. 110:983-990.

5. Berry, D., and Cilas, C. 1994. Etude génétique de la réaction à la pourriture brune des cabosses de cacaoyers issus d'un plan de croisement diallèle. Agronomie 14:599-609.

6. Blaha, G., and Lotodé, R. 1976. Un critère primordial de sélection du cacaoyer au Cameroun: La résistance à la pourriture brune des cabosses (Phytophthora palmivora). Variations des réactions à la maladie en liaison avec les données écologiques et l'état physiologique des fruits. Café Cacao Thé XX:97-116.

7. Bowers, J. H., Bailey, B. A., Hebbar, P. K., Sanogo, S., and Lumsden, R. D. 2001. The impact of plant diseases on world chocolate production. Online. Plant Health Progress doi:10.1094/PHP-2001-0709-01-RV.

8. Cilas, C., Berry, D., Paulin, D., N'Goran, J. A. K., and Djiekpor, E. K. 1999. La résistance à la pourriture brune des cabosses au Cameroun, en Côte d'Ivoire et au Togo. Bilan d'évaluation au champ. Pages 367-373 in: Proc. 12th Int. Cocoa Res. Conf., Salvador, Bahia, Brazil. Cocoa Producers' Alliance (COPAL), Malaysia.

9. Cronshaw, D. K., and Evans, H. C. 1978. Witches' broom disease of cocoa (Crinipellis perniciosa) in Ecuador. II. Methods of infection. Ann. Appl. Biol. 89:193-200.

10. Despréaux, D., Cambrony, D., Clément, D., Nyassé, S., and Partiot, M. 1988. Etude de la pourriture brune des cabosses du cacaoyer au Cameroun: Définition de nouvelles méthodes de lutte. Pages 407-412 in: Proc. 10th Int. Cocoa Res. Conf., Santo Domingo, Dominican Republic. Cocoa Producers' Alliance (COPAL), UK.

11. Despréaux, D., Clément, D., and Partiot, M. 1989. La pourriture brune des cabosses du cacaoyer au Cameroun: Mise en évidence d'un caractère de résistance au champ. Agronomie 9:683-691. 
12. Efombagn, M. I. B., Marelli, J. P., Ducamp, M., Cilas, C., Nyasse, S., and Vefonge, D. 2004. Effect of fruiting traits on the field resistance of cocoa (Theobroma cacao L.) clones to Phytophthora megakarya. J. Phytopathol. 152:557-562.

13. Efron, Y., Blaha, G., and Epaina, P. 2002. Is the resistance to Phytophthora pod rot mainly polygenic and additive? Ingenic Newsl. 7:2-4.

14. Evans, H. C. 1980. Pleomorphism in Crinipellis perniciosa, causal agent of Witches' Broom disease of cocoa. Trans. Br. Mycol. Soc. 74:515-523.

15. Evans, H. C., and Bastos, C. N. 1981. Preliminary results of research on Witches' Broom disease of cacao (Crinipellis perniciosa) in the Amazonian region of Brazil. Pages 255-256 in: Proc. 7th Int. Cocoa Res. Conf., Douala, Cameroun. Cocoa Producers' Alliance (COPAL), UK.

16. Falconer, D. S. 1986. Introduction to Quantitative Genetics. Longman Scientific \& Technical, New York.

17. Frias, G. A., Purdy, L. H., and Schmidt, R. A. 1991. Infection biology of Crinipellis perniciosa on vegetative flushes of cacao. Plant Dis. 75:552-556.

18. Gonsalves, C. 1996. History of cocoa breeding in the Ministry of Agriculture, Trinidad. Cocoa Res. Unit Newsl. 3:4-6.

19. Hintze, J. 2001. NCSS and PASS. Number Cruncher Statistical System, Kaysville, UT

20. Iwaro, A. D., Bekele, F. L., and Butler, D. R. 2003. Evaluation and utilisation of cacao (Theobroma cacao L.) germplasm at the International Cocoa Genebank, Trinidad. Euphytica 130:207-221.

21. Iwaro, A. D., Sreenivasan, T. N., Butler, D. R., and Umaharan, P. 2000. Rapid screening for Phytophthora pod rot resistance by means of detached pod inoculation. Pages 109-113 in: Working Procedures for Cocoa Germplasm Evaluation and Selection. A. B. Eskes, J. M. M. Engels, and R. A. Lass, eds. Proc. CFC/ICCO/IPGRI Project Workshop, Montpellier, France.

22. Iwaro, A. D., Sreenivasan, T. N., and Umaharan, P. 1997. Phytophthora resistance in cacao (Theobroma cacao): Influence of pod morphological characteristics. Plant Pathol. 46:557-565.

23. Iwaro, A. D., Umaharan, P., and Sreenivasan, T. N. 1997. Inheritance of foliar resistance to Phytophthora palmivora (Butler) Butler in cacao (Theobroma cacao L.). Euphytica 96:377-383.

24. Kébé, I. B., N'Goran, J. A. K., Tahi, G. M., Paulin, D., Clément, D., and Eskes, A. B. 1999. Pathology and breeding for resistance to black pod in Côte d'Ivoire. Pages 135-139 in: Proc. Int. Workshop on the Contribution of Disease Resistance to Cocoa Variety Improvement. Salvador, Bahia, Brazil. INGENIC, UK.

25. Lass, R. A. 1985. Chapter 11: Diseases. Pages 265-365 in: Cocoa. 4th ed. G. A. R. Wood and R. A. Lass, eds. Longman Group Limited, London.

26. Lauckner, F. B., and Fielding, W. J. 1991. Biometric notes for agricultural research in the Caribbean. 2nd ed. Caribbean Agricultural Research and Development Institute, UWI, Trinidad and Tobago.

27. Luz, E. D. M. N., Silva, S. D. V. M., Albuquerque, P. S. B., Pinto, L. R. M., Brugnerotto, M. I., and Paim, M. C. A. 1999. Evaluation of cocoa progenies in Bahia, Brazil, for resistance to Crinipellis perniciosa. Pages 219-226 in: Proc. 12th Int. Cocoa Res. Conf., Salvador, Bahia, Brazil. Cocoa Producers' Alliance (COPAL), Malaysia.

28. Maddison, A. C., and Griffin, M. J. 1981. Detection and movement of inoculum. Pages 31-49 in: Epidemiology of Phytophthora on Cocoa in Nigeria. P. H. Gregory and A. C. Maddison, eds. Phytopathological Paper No. 25, Commonwealth Mycological Institute, Kew, England.

29. Maddison, A. C., and Idowu, O. L. 1981. The epidemic on sprayed cocoa at Owena. Pages 163-172 in: Epidemiology of Phytophthora on Cocoa in Nigeria. P. H. Gregory and A. C. Maddison, eds. Phytopathological Paper No. 25, Commonwealth Mycological Institute, Kew, England.

30. Medeiros, A. G. 1977. Sporulation of Phytophthora palmivora Butl. (Butl.) in relation to epidemiology and control of cacao black pod disease. Publição Especial. CEPLAC, Itabuna, Brazil.

31. Montserin, B. G., de Verteuil, L. L., and Freeman, W. E. 1957. A note on cacao hybridisation in Trinidad with reference to clonal selection and hybrid seedlings. Caribbean Commission Public Exchange Service $33: 155-164$.

32. Motilal, L., and Butler, D. 2003. Verification of identities in global cacao germplasm collections. Gen. Res. Crop Evol. 50:799-807.

33. Nyassé, S., Despreaux, D., and Cilas, C. 2002. Validity of a leaf inoculation test to assess the resistance to Phytophthora megakarya in a cocoa
(Theobroma cacao L.) diallel mating design. Euphytica 123:395-399.

34. Opeke, L. K., and Gorenz, A. M. 1974. Phytophthora pod rot: Symptoms and economic importance. Pages 117-124 in: Phytophthora Disease of Cocoa. P. H. Gregory, ed. Longman Group Limited, London.

35. Partiot, M. 1975. La résistance horizontale du cacaoyer au Phytophthora sp. Méthodes d'évaluation précoce. Café Cacao Thé XIX:123-136.

36. Pires, J. L., Monteiro, W. R., Luz, E. D. M. N., Silva, S. D. V. M., Pinto, L. R. M., Figueira, A., Gramacho, K. P., Lopes, U. V., Beviláquia Albuquerque, P. S., Yamada, M. M., Ahnert, D. E., and Brugnerotto, M. I. B. 1999. Cocoa breeding for witches' broom resistance at CEPEC, Bahia, Brazil. Pages 91-101 in: Proc. Int. Workshop on the Contribution of Disease Resistance to Cocoa Variety Improvement. Salvador, Bahia, Brazil. INGENIC, UK

37. Pires, J. L., Monteiro, W. R., Pinto, L. R. M., and Luz, E. D. M. N. 1999. Resistance to Witches' Broom-Evaluation of genotypes from different origins. Pages 389-397 in: Proc. 12th Int. Cocoa Res. Conf., Salvador, Bahia, Brazil. Cocoa Producers' Alliance (COPAL), Malaysia.

38. Purdy, L. H., Dickstein, E. R., and Schmidt, R. A. 1998. Relative resistance of cacao clones to Crinipellis perniciosa determined by artificial inoculation using an automated basidiospore spray system. Agrotrópica 10:9-12.

39. Purdy, L. H., Schmidt, R. A., Dickstein, E. R., and Frias, G. A. 1997. An automated system for screening Theobroma cacao for resistance to witches' broom. Agrotrópica 9:119-126.

40. Rudgard, S. A. 1989. Detailed description of symptoms of witches' broom disease of cocoa caused by Crinipellis perniciosa. Cocoa Growers' Bull. 41:1-32.

41. Rudgard, S. A., Maddison, A. C., and Andebrhan, T. (eds.) 1993. Disease management in cocoa. Comparative epidemiology of Witches' Broom. Chapman \& Hall, New York.

42. SAS Institute. 1997. SAS User's guide version 6.12. SAS Institute, Cary, NC.

43. Shripat, C. 2001. Black Pod disease control by single fungicide application. Pages 681-687 in: Proc. 13th Int. Cocoa Res. Conf., vol. 1, Kota Kinabalu, Sabah-Malaysia. Cocoa Producers' Alliance (COPAL), Malaysia.

44. Silva, S. D. V. M., Luz, E. D. M. N., de Almeida, O. C., Gramacho, K. P., and Bezerra, J. L. 2002. Redescrição da sintomatologia causada por Crinipellis perniciosa em cacaueiro. Agrotrópica 14:1-24.

45. Simmonds, N. W. 1994. Horizontal resistance to cocoa diseases. Cocoa Growers' Bull. 47:42-53.

46. Sreenivasan, T. N., and Dabydeen, S. 1989. Modes of penetration of young cocoa leaves by Crinipellis perniciosa. Plant Dis. 73:478-481.

47. Surujdeo-Maharaj, S., Umaharan, P., Butler, D. R., and Sreenivasan, T. N. 2003. An optimized screening method for identifying levels of resistance to Crinipellis perniciosa in cocoa (Theobroma cacao). Plant Pathol. 52:464-475.

48. Tan, G.-Y., and Tan, W.-K. 1990. Additive inheritance of resistance to pod rot caused by Phytophthora palmivora in cocoa. Theor. Appl. Genet. $80: 258-264$

49. Tarjot, M. 1972. Etude anatomique de la cabosse de cacaoyer en relation avec l'attaque du Phytophthora palmivora. Café Cacao Thé XVI:123-134.

50. Umaharan, R., Thevenin, J.-M., and Surujdeo-Maharaj, S. 2002. Evaluation of cocoa germplasm for resistance to Witches' Broom disease. Pages 38-41 in: Annual Report 2001. Cocoa Research Unit, The University of the West Indies, Trinidad and Tobago.

51. Van der Vossen, H. A. M. 1997. Strategies of variety improvement in cocoa with emphasis on durable disease resistance. An external review prepared for INGENIC, the University of Reading, UK.

52. Verbeke, G., and Molenberghs, G. 2000. Linear Mixed Models for Longitudinal Data. Springer-Verlag, New York.

53. Wadsworth, R. M., Ford, C. S., End, M. J., and Hadley, P. 1997. International Cocoa Germplasm Database. The London International Financial Futures and Options Exchange/The University of Reading, London, UK.

54. Wheeler, B. E. J., and Mepsted, R. 1988. Pathogenic variability amongst isolates of Crinipellis perniciosa from cocoa (Theobroma cacao). Plant Pathol. 37:475-488

55. Zadoks, J. C. 1997. Disease resistance testing in cocoa. A review on behalf of FAO/INGENIC, the University of Reading, UK. 